\title{
GTF2F1 Gene
}

National Cancer Institute

\section{Source}

National Cancer Institute. GTF2F1 Gene. NCI Thesaurus. Code C20652.

This gene plays a role in the maintenance of transcriptional integ rity. 